Aspirasi: Jurnal Masalah-Masalah Sosial | Volume 10, No. 1 Juni 2019

ISSN: 2086-6305 (print) ISSN: 2614-5863 (electronic)

DOI: https://doi.org/10.22212/aspirasi.v7il.1084

link online: http://jurnal.dpr.go.id/index.php/aspirasi/index

\title{
PERAN SEKOLAH DAN MASYARAKAT DALAM PELAKSANAAN PROGRAM BANTUAN OPERASIONAL SEKOLAH
}

\author{
School and Community's Participation on the Implementation of School Operational \\ Grant Program \\ Yulia Indahri \\ yulia.indahri@dpr.go.id \\ Pusat Penelitian Badan Keahlian DPR RI \\ Jl. Gatot Subroto Senayan Jakarta
}

Naskah Diterima: 28 Maret 2019 | Naskah direvisi: 20 Juni 2019 | Naskah diterbitkan: 29 Juni 2019

\begin{abstract}
School Operational Grant (BOS) is a program that absorbs large enough funds and received directly by beneficiaries, schools. The BOS program began on July 2005 in order to accelerate 9-year compulsory education, reduce dropout rates, and assist students from poor families to continue schooling. However, there were also an indication that the government wanted to invite stakeholders, namely schools and the committee, to actively involve in the implementation of the program. Although the funds received by students through their school have not reached the ideal, at least the minimum service requirement can be met. This paper uses literature studies and field studies in three provinces in Indonesia, namely Aceh, West Kalimantan, and North Sulawesi for comparison. Literature studies among which are based on the study and research conducted on the BOS Program by third parties such as SMERU and the World Bank. While field studies were conducted in order to understand problems on the implementation of BOS Program especially on stakeholders' participation. As conclusion, it is seen that the addition of budget allocations should continue to pay more attention to suggestions from provincial/district/city governments, as well as from the community. Community participation, especially when it comes to funding, should not be unsupervised. There must be certainty of transparency and accountability of the use of funds that are constantly being reported to the public and not of a coercive nature.
\end{abstract}

Keywords: grant, education, school.

\begin{abstract}
Abstrak: Bantuan Operasional Sekolah (BOS) merupakan program yang menyerap dana cukup besar dan langsung diterima oleh penerima bantuan, yaitu sekolah. Program BOS mulai dilaksanakan pada Juli 2005 dalam rangka percepatan Wajib Belajar 9 Tahun, menekan angka putus sekolah, dan membantu siswa dari keluarga miskin untuk dapat terus sekolah. Akan tetapi, ada keinginan dari pemerintah agar pemangku kepentingan, yakni sekolah dan komite sekolah, mau terlibat aktif dalam pelaksanaan program. Walaupun dana yang diterima oleh siswa melalui sekolah belum mencapai angka ideal, paling tidak kebutuhan standar pelayanan minimal dapat terpenuhi. Tulisan ini menggunakan studi pustaka dan studi lapangan di tiga provinsi di Indonesia, yaitu Aceh, Kalimantan Barat, dan Sulawesi Utara untuk perbandingan. Studi pustaka di antaranya adalah kajian dan penelitian yang dilakukan mengenai Program BOS oleh lembaga penelitian SMERU dan juga Bank Dunia. Studi di lapangan dilakukan untuk melihat kendala yang ditemui di lapangan dalam pelaksanaan Program BOS terutama dalam kaitannya dengan peran serta pemangku kepentingan. Dapat disimpulkan bahwa penambahan alokasi anggaran perlu terus mendengarkan masukan dari pemerintah provinsi/kabupaten/kota, dan juga dari masyarakat. Partisipasi masyarakat, terutama jika menyangkut pendanaan, tidak berarti tanpa pengawasan. Harus ada kepastian transparansi dan akuntabilitas dari pemanfaatan dana yang tetap dilaporkan ke masyarakat dan tidak bersifat memaksa.
\end{abstract}

Kata kunci: bantuan, pendidikan, sekolah. 


\section{Pendahuluan}

Undang-Undang Nomor 20 Tahun 2003 tentang Sistem Pendidikan Nasional (UU Sisdiknas) mengamanatkan bahwa setiap warga negara yang berusia 7 s.d. 15 tahun wajib mengikuti pendidikan dasar. Pasal 34 ayat (2) menyebutkan bahwa pemerintah dan pemerintah daerah menjamin terselenggaranya wajib belajar minimal pada jenjang pendidikan dasar tanpa memungut biaya, sedangkan ayat (3) mengatur bahwa wajib belajar merupakan tanggung jawab negara yang diselenggarakan oleh lembaga pendidikan pemerintah, pemerintah daerah, dan masyarakat. Konsekuensi dari amanat UU Sisdiknas adalah pemerintah dan pemerintah daerah wajib memberikan layanan pendidikan bagi seluruh peserta didik pada tingkat pendidikan dasar (SD dan SMP) serta satuan pendidikan lain yang sederajat.

Program Bantuan Operasional Sekolah (BOS) dilatarbelakangi oleh kenaikan harga minyak dunia pada tahun 2005 yang pada saat itu mencapai tingkat tertinggi selama kurun waktu 25 tahun terakhir. Kenaikan yang mencapai sekitar USD70 per barel telah memaksa pemerintah melakukan pengurangan subsidi untuk Bahan Bakar Minyak (BBM) sebanyak dua kali pada bulan Maret dan Oktober (Bank Indonesia, 2005). Program BOS muncul sesudah program hibah kecil untuk sekolah yang diperkenalkan setelah krisis ekonomi di tahun 1997. Secara konseptual Program BOS berbeda dengan program kompensasi pengurangan subsidi bahan bakar minyak bidang pendidikan setelah krisis tersebut. Tujuan program ini adalah untuk mengukur beban keuangan pemerintah bagi pendidikan dalam rangka menyediakan program wajib belajar 9 tahun yang bermutu serta untuk mendukung reformasi manajemen berbasis sekolah (Bank Dunia, 2015: 2). Program BOS mengadopsi pendekatan yang berbeda karena dana tidak diberikan kepada siswa miskin tetapi diberikan dan dikelola oleh sekolah (SMERU, 2006: 7).

Peraturan MenteriPendidikandanKebudayaan Republik Indonesia No. 76 Tahun 2012 tentang Juknis Penggunaan dan Pertanggungjawaban Keuangan Dana BOS Tahun 2013 menyebutkan bahwa pada awalnya program BOS bertujuan 50 untuk meringankan beban masyarakat terhadap pembiayaan pendidikan dalam rangka wajib belajar 9 tahun yang bermutu. Tetapi setelah melalui evaluasi dalam kurun waktu lebih dari sepuluh tahun, sasaran dana BOS tidak hanya untuk tingkat SD dan SMP saja, tetapi juga sekolah menengah atas/kejuruan dan semua jenjang sekolah luar biasa.

Salah satu peran program BOS selain untuk meningkatkan angka partisipasi siswa adalah sebagai komponen penting bagi upaya pemerintah untuk melaksanakan reformasi manajemen berbasis sekolah dalam rangka meningkatkan peran serta sekolah dan masyarakat (Bank Dunia, 2015: 10). Pada tahun 2001, tanggung jawab layanan pendidikan dasar sebagian besar diserahkan kepada pemerintah daerah. Reformasi lebih lanjut diperkenalkan pada tahun 2003 yang memberikan landasan hukum bagi manajemen berbasis sekolah dan komite sekolah dalam upaya untuk mendorong partisipasi masyarakat setempat dan memperkuat akuntabilitas antara sekolah dan orang tua. Program BOS mendukung reformasi ini dengan menyediakan sumber daya untuk mendanai rencana perbaikan sekolah, dan dengan memanfaatkan struktur manajemen berbasis sekolah yang telah terbentuk serta proses untuk mengatur penggunaan dana.

Tulisan ini menggunakan studi pustaka dan studi lapangan di tiga provinsi di Indonesia, yaitu Aceh, Kalimantan Barat, dan Sulawesi Utara untuk perbandingan. Studi pustaka di antaranya adalah kajian dan penelitian yang dilakukan terhadap program BOS oleh lembaga penelitian SMERU dan Bank Dunia. Studi di lapangan menggunakan metode kualitatif melalui wawancara dengan pihak sekolah dan komite sekolah, selanjutnya kegiatan pengumpulan data dan analisis data penelitian dilakukan secara simultan. Pengumpulan data merupakan bagian integral dari kegiatan analisis data. Oleh karena itu, penelitian ini menggunakan analisis data model interaktif yang dilakukan melalui tiga alur kegiatan, yaitu: 1) reduksi data, 2) displai data, dan 3) penarikan kesimpulan/verifikasi (Miles \& Huberman, 1994: 10).

Pengambilan datalapanganmerupakan bagian dari kegiatan turun lapangan yang dilakukan oleh Aspirasi Val 10 Na 1, Tuni 2019 
peneliti Pusat Penelitian Badan Keahlian DPR RI di beberapa kota besar di Indonesia. Berdasarkan analisis yang dilakukan untuk mengetahui kendala dalam keikutsertaan pemangku kepentingan dalam pelaksanaan Program BOS, ditemukan bahwa penambahan alokasi anggaran perlu terus mendengarkan masukan dari pemerintah provinsi/kabupaten/kota, dan juga dari masyarakat. Partisipasi masyarakat, terutama jika menyangkut pendanaan, tidak berarti tanpa pengawasan. Harus ada kepastian transparansi dan akuntabilitas dari pemanfaatan dana yang tetap dilaporkan ke masyarakat dan tidak bersifat memaksa.

\section{Kebijakan Pendanaan Pendidikan Nasional}

Penyelenggaraan pendidikan yang lebih berkualitas terus didorong sejak bergulirnya reformasi dan diterapkannya desentralisasi. Sejak tahun 2001, tanggung jawab penyelenggaraan pendidikan diserahkan kepada pemerintah provinsi/kabupaten/kota. Selanjutnya, sejak tahun 2003, ketika UU Sisdiknas disahkan, UU tersebut menjadi dasar hukum manajemen berbasis sekolah dan diformalkannya komite sekolah yang merupakan wadah bagi masyarakat untuk berperan aktif dalam memajukan pendidikan.

Pada tahun 2005, dengan disahkannya Undang-Undang Nomor 14 Tahun 2005 tentang Guru dan Dosen (UUGD), maka berbagai upaya dilakukan untuk mengatasi kekurangan dalam pendapatan dan kualitas guru melalui program sertifikasi yang diiringi dengan peningkatan remunerasi dan pengembangan profesi berkelanjutan bagi tenaga kependidikan. Pada saat yang sama, mulai diperkenalkan Program BOS sebagai bentuk bantuan terhadap satuan pendidikan yang menjadi ujung tombak pendidikan nasional. Mengacu pada Rencana Pembangunan Jangka Menengah Nasional (RPJMN), hingga saat ini sudah tiga periode RPJMN yang dilalui Indonesia.

Pada periode 2004-2009, RPJMN dituangkan dalam Peraturan Presiden Nomor 7 Tahun 2005. Prioritas kebijakan pendidikan dalam kurun waktu tersebut ada pada peningkatan akses masyarakat terhadap pendidikan dasar yang lebih berkualitas melalui peningkatan pelaksanaan wajib belajar sembilan tahun dan pemberian akses yang lebih besar kepada kelompok masyarakat yang kurang dapat menjangkau layanan pendidikan dasar. Implementasi dari kebijakan tersebut adalah penyediaan pembiayaan pendidikan melalui BOS. Program BOS merupakan pengembangan lebih lanjut dari program Jaring Pengaman Sosial (JPS) bidang pendidikan pada kurun 1998-2003, yang juga sekaligus sebagai program kompensasi pengurangan subsidi BBM yang dilaksanakan kurun 2003-2005 (Kharisma, 2013: 7).

Pada periode 2010-2014, melalui RPJMN yang tertuang dalam Peraturan Presiden Nomor 5 Tahun 2010, capaian strategis dalam pembangunan pendidikan adalah terjaminnya kepastian memperoleh layanan pendidikan sekolah dasar bermutu dan berkesetaraan. Implementasi dari kebijakan tersebut selain penyediaan pembiayaan pendidikan melalui BOS juga dilakukan dalam bentuk bantuan biaya personal melalui Bantuan Siswa Miskin (BSM).

Meski dana BOS diharapkan dapat meningkatkan jumlah keikutsertaan siswa/ peserta didik, tetapi masih banyak anak-anak yang tidak dapat bersekolah, putus sekolah, dan tidak dapat melanjutkan pendidikan mereka ke jenjang pendidikan berikutnya. Salah satu penyebab hal tersebut adalah kesulitan orang tua/ keluarga dalam memenuhi kebutuhan pendidikan lainnya seperti baju seragam, buku tulis, sepatu, biaya transportasi maupun biaya pendidikan lainnya yang tidak ditanggung oleh dana BOS, sehingga dikembangkanlah Program BSM (TNP2K, 2018).

Rencana strategis nasional bidang pendidikan pada periode 2015-2019 mengikuti program prioritas nasional yang tertuang dalam nawacita. RPJMN 2015-2019 merupakan tahap ketiga dari pelaksanaan Rencana Pembangunan Jangka Panjang Nasional (RPJPN) 2005-2025 yang ditetapkan melalui Peraturan Presiden Nomor 2 Tahun 2015. Selain kembali menyediakan pembiayaan pendidikan melalui BOS, pemerintah juga memperkenalkan Program Indonesia Pintar (PIP). 
PIP adalah salah satu program nasional yang bertujuan untuk meningkatkan angka partisipasi pendidikan dasar dan menengah; meningkatkan angka keberlanjutan pendidikan; menurunkan angka kesenjangan partisipasi pendidikan antarkelompok masyarakat (kaya-miskin, lakilaki-perempuan, perkotaan-perdesaan, dan antardaerah); serta meningkatkan kesiapan siswa pendidikan menengah untuk memasuki pasar kerja atau melanjutkan ke jenjang pendidikan tinggi (TNP2K, 2018).

Dari berbagai program pendanaan pendidikan yang secara singkat telah dijabarkan di atas, BOS menjadi program yang berupaya untuk membantu siswa dari keluarga miskin untuk dapat terus bersekolah.

\section{Perkembangan Program Bantuan Operasional Sekolah}

Sebagai program nasional Program BOS membantu penyediaan pendanaan biaya operasi nonpersonil sekolah, walaupun ada beberapa pembiayaan personil yang masih dapat dibayarkan dari dana BOS. Dampak Program BOS juga dirasakan karena telah membebaskan pungutan operasional bagi peserta didik pada sekolah yang diselenggarakan oleh pemerintah kabupaten/kota, dan meringankan pungutan operasional bagi peserta didik dengan orang tua/wali yang tidak mampu pada sekolah yang diselenggarakan oleh masyarakat. Capaian utama BOS adalah semua satuan pendidikan di tingkat SD, SMP, SMA, SMA, SMK, dan SLB (SDLB, SMPLB, SMALB), serta Satuan Pendidikan SDSMP Satu Atap (SATAP) baik negeri maupun swasta di seluruh provinsi di Indonesia yang sudah memiliki Nomor Pokok Sekolah Nasional (NPSN) dan sudah terdata dalam sistem Data Pokok Pendidikan (Dapodik).

Pada awalnya, pembebasan biaya operasional berlaku bagi seluruh peserta didik di tingkat SD/SDLB, SMP/SMPLB, dan SATAP. Sejak tahun 2013, sasaran BOS diperluas sampai ke jenjang pendidikan SMA/SMK seperti terlihat pada Tabel 1. BOS tidak hanya membebaskan biaya operasional bagi seluruh peserta didik di jenjang pendidikan dasar, tetapi sejak 2013 telah membebaskan biaya bagi peserta didik yang orang tua/walinya tidak mampu dan/atau membantu (memberikan discount fee) tagihan biaya sekolah.

Tabel 1. Perkembangan Program BOS 2005-2018

\begin{tabular}{cl}
\hline \multicolumn{1}{c}{ Tahun } & \multicolumn{1}{c}{ Keterangan } \\
\hline 2005-2012 & Wajib Belajar 9 Tahun \\
& sasaran BOS: SD/SDLB, SMP/ \\
& SMPLB/SATAP \\
2013 -2018 & menuju wajib belajar 12 tahun \\
& sasaran BOS: SD/SDLB, SMP/ \\
& SATAP/SMA/SM \\
\hline
\end{tabular}

Sumber: Kemendikbud, 2018

Menurut Priowirjanto et al. (2008), Dapodik yang menjadi pangkalan data utama pelaksanaan Program BOS diperlukan untuk membangun program perencanaan pendidikan yang valid, terukur dan berkesinambungan. Biro Perencanaan Sekretariat Jenderal Kementerian Pendidikan dan Kebudayaan telah membangun sistem pendataan dalam skala mikro secara terpusat, dalam jaringan (online) dan waktu nyata (real time). Untuk mendukung sistem Dapodik tersebut, telah juga dibangun sistem jaringan pendidikan skala nasional yang disebut dengan Jejaring Pendidikan Nasional (Jardiknas). Sistem Dapodik ini mulai diterapkan sejak September 2006.

Tabel 2. Perkembangan Biaya Satuan Dana BOS Tingkat SD/SDLB, 2005-2019

\begin{tabular}{ll}
\hline \multicolumn{1}{c}{ Tahun } & \multicolumn{1}{c}{ Biaya Satuan } \\
\hline $2005-2006$ & Rp235.000 \\
$2007-2008$ & Rp254.000 \\
$2009-2011$ & Kab. Rp397.000 \\
& Kota Rp400.000 \\
$2012-2014$ & Rp580.000 \\
$2015-2019$ & Rp800.000 \\
\hline Sumber: Kemendikbud, 2019
\end{tabular}

Sejak BOS diluncurkan, telah beberapa kali diadakan evaluasi untuk peningkatan angka bantuan yang diterima siswa per tahun. Seperti dapat dilihat pada Tabel 2, angka yang diterima siswa (tingkat $\mathrm{SD} / \mathrm{SDLB} / \mathrm{MI}$ ) terus mengalami peningkatan. Awalnya dana yang diterima oleh siswa SD adalah Rp235.000 per anak per tahun. 
Kemudian meningkat menjadi Rp254.000, Rp400.000, Rp580.000, dan terakhir sampai dengan tahun 2019, dana yang diterima oleh siswa SD adalah Rp800.000 per anak per tahun.

Alokasi siswa penerima dana BOS mengalami beberapa kali peningkatan dan penurunan, yang sangat dipengaruhi oleh jumlah peserta didik di satuan pendidikan. Selain itu karena pengelolaan dana BOS untuk MI diserahkan kepada Kementerian Agama sejak 2007 (Tabel 3).

Tabel 3. Perkembangan Jumlah Siswa Penerima Dana BOS Tingkat SD/SDLB, 2005-2018

\begin{tabular}{cc}
\hline Tahun & Alokasi Siswa Satuan \\
\hline 2005 & 28.887 .886 \\
2006 & 29.432 .530 \\
2007 & 26.046 .328 \\
2008 & 26.862 .332 \\
2009 & 26.866 .992 \\
2010 & 27.166 .972 \\
2011 & 27.323 .343 \\
2012 & 27.153 .667 \\
2013 & 26.875 .203 \\
2014 & 26.423 .084 \\
2015 & 26.499 .418 \\
2016 & 26.565 .667 \\
2017 & 25.615 .248 \\
2018 & 25.925 .487 \\
\hline
\end{tabular}

Sumber: Kemendikbud, 2018

Komponen BOS untuk SD/SDLB dan SMP/ SMPLB, adalah:

1. pengembangan perpustakaan;

2. kegiatan penerimaan siswa baru;

3. kegiatan pembelajaran dan ekstra kurikuler;

4. kegiatan evaluasi pembelajaran;

5. pembiayaan pengelolaan sekolah;

6. pengembangan profesi guru;

7. langganan daya dan jasa;

8. pemeliharaan dan perawatan sekolah;

9. gaji honorarium bulanan;

10. pembelian/perawatan alat multimedia pembelajaran; dan

11. biaya lainnya jika semua komponen telah terpenuhi pendanaan dari BOS.

Sedikit berbeda dari komponen BOS untuk pendidikan dasar, pada SMA/SMALB komponen
BOS diperuntukkan bagi:

1. pengembangan perpustakaan;

2. penerimaan peserta didik baru;

3. kegiatan pembelajaran dan ekstra kurikuler;

4. kegiatan evaluasi pembelajaran;

5. pembiayaan pengelolaan sekolah;

6. kegiatan peningkatan kualitas pembelajaran dan manajemen sekolah;

7. langganan daya dan jasa;

8. pemeliharaan dan perawatan sekolah;

9. gaji honorarium bulanan; dan

10. pembelian/perawatan alat multimedia pembelajaran.

Sedangkan pada SMK, komponen peruntukan BOS adalah untuk:

1. pengembangan perpustakaan;

2. penerimaan peserta didik baru;

3. kegiatan pembelajaran dan ekstra kurikuler;

4. kegiatan evaluasi pembelajaran;

5. pembiayaan pengelolaan sekolah;

6. kegiatan peningkatan kualitas pembelajaran dan manajemen sekolah;

7. langganan daya dan jasa;

8. pemeliharaan dan perawatan sekolah;

9. gaji honorarium bulanan;

10. pembelian alat multimedia pembelajaran;

11. penyelenggaraan kegiatan Uji Kompetensi dan Sertifikasi Kejuruan; serta

12. penyelenggaraan Bursa Kerja Khusus SMK dan praktik kerja industri.

Dalam pemanfaatannya, dana BOS tidak boleh:

1. disimpan dalam jangka waktu lama dengan maksud dibungakan;

2. dipinjamkan kepada pihak lain;

3. membeli software/perangkat lunak untuk pelaporan keuangan BOS;

4. membiayai kegiatan bukan prioritas sekolah misalnya studi banding, tur studi (karya wisata) dan sejenisnya;

5. membayar iuran kegiatan yang diselenggarakan oleh Unit Pelaksana Teknis Daerah (UPTD), kecuali untuk menanggung biaya peserta didik-guru yang ikut serta dalam kegiatan;

6. membiayai bonus dan transportasi rutin untuk guru;

7. membeli pakaian/seragam/sepatu bagi guru/ 
peserta didik untuk kepentingan pribadi (bukan inventaris sekolah);

8. digunakan untuk rehabilitasi sedang dan berat;

9. membangun gedung/ruangan baru;

10. membeli Lembar Kerja Siswa (LKS) dan bahan/peralatan yang tidak mendukung proses pembelajaran;

11. menanamkan saham;

12. membiayai kegiatan yang telah dibiayai dari sumber dana pemerintah pusat atau pemerintah daerah secara penuh/wajar;

13. membiayai kegiatan penunjang yang tidak ada kaitannya dengan operasi satuan pendidikan, misalnya membiayai upacara keagamaan/ acara keagamaan, dan iuran dalam rangka upacara peringatan hari besar nasional;

14. membiayai kegiatan dalam rangka mengikuti pelatihan/sosialisasi/pendampingan terkait program BOS/perpajakan program BOS yang diselenggarakan lembaga di luar SKPD Pendidikan Provinsi/Kabupaten/Kota dan Kementerian Pendidikan dan Kebudayaan; serta

15. membayar honorarium kepada guru dan tenaga kependidikan atas tugas/kegiatan yang sudah merupakan tugas pokok dan fungsi yang telah diatur dalam peraturan perundangan yang berlaku, termasuk pembayaran honorarium bagi panitia untuk kegiatan-kegiatan yang sudah menjadi tupoksi satuan pendidikan/guru.

Ketentuan tambahan dana BOS untuk SMA/ SMALB:

1. tidak boleh digunakan untuk membiayai kegiatan yang sama yang telah dibiayai oleh pemerintah pusat/pemerintah daerah/ masyarakat;

2. penggunaan terkait konsumsi, transportasi, dan/atau honor mengikuti ketentuan daerah setempat yang ditetapkan;

3. standar biaya untuk konsumsi, transportasi, jasa profesi dan/atau upah tukang sesuai dengan standar biaya setempat yang ditetapkan;

4. jasa profesi hanya diberikan kepada narasumber yang mewakili instansi resmi di luar sekolah, misalnya Kwarda, KONI daerah, BNN, dinas pendidikan, dinas kesehatan, unsur keagamaan, dan/ atau lainnya berdasarkan surat tugas yang dikeluarkan oleh instansi yang diwakilinya; serta

5. standar biaya untuk honor petugas pendataan Dapodik dan guru pembimbing sesuai dengan standar biaya, ketentuan, atau kewajaran yang berlaku di daerah sesuai dengan beban kerja yang ditetapkan.

Ketentuan tambahan Dana BOS untuk SMK:

1. tidak boleh digunakan untuk membiayai kegiatan yang telah dibiayai oleh pemerintah pusat/pemerintah daerah/masyarakat;

2. penggunaan terkait konsumsi, transportasi, dan/atau honor mengikuti ketentuan daerah setempat;

3. jasa profesi hanya diberikan kepada narasumber yang mewakili instansi resmi di luar sekolah, misalnya Kwarda, KONI daerah, BNN, dinas pendidikan, dinas kesehatan, unsur keagamaan, dan/atau lainnya berdasarkan surat tugas yang dikeluarkan oleh instansi yang diwakilinya;

4. pembiayaan perjalanan dinas yaitu biaya transportasi akomodasi dan/atau uang harian sesuai dengan standar biaya setempat;

5. standar biaya untuk konsumsi, transportasi, jasa profesi, dan/atau upah tukang sesuai dengan standar biaya setempat;

6. standar biaya untuk honor petugas pendataan Dapodik dan guru pembimbing sesuai dengan standar biaya, ketentuan, atau kewajaran yang berlaku di daerah sesuai dengan beban kerja;

7. membebaskan pungutan bagi seluruh siswa SD/SDLB negeri dan SMP/SMPLB/SMPT (Terbuka) negeri terhadap biaya operasi sekolah, kecuali pada rintisan sekolah bertaraf internasional (RSBI) dan sekolah bertaraf internasional (SBI). Sumbangan/ pungutan bagi sekolah RSBI dan SBI harus tetap mempertimbangkan fungsi pendidikan sebagai kegiatan nirlaba, sehingga sumbangan/pungutan tidak boleh berlebih;

8. membebaskan pungutan seluruh siswa miskin dari seluruh pungutan dalam bentuk apapun, baik di sekolah negeri maupun swasta; serta

9. meringankan beban biaya operasi sekolah bagi siswa di sekolah swasta. 
Berbagai ketentuan tersebut termuat dalam petunjuk teknis dan peraturan-peraturan yang menjadi pedoman, seperti:

1. Peraturan Presiden No. 107/2017 tentang Rincian Anggaran Pendapatan dan Belanja Negara Tahun 2018;

2. PMK No. 112/PMK.07/2017 tentang Perubahan atas PMK No 50/PMK.07/2017 tentang Pengelolaan Transfer ke Daerah dan Dana Desa;

3. Permendagri No $33 / 2017$ tentang Pedoman Penyusunan APBD Tahun Anggaran 2018;

4. Permendikbud No. 1/2018 tentang Petunjuk Teknis Bantuan Operasional Sekolah; serta

5. SEMendagriNo. 910/106/SJ tentang Petunjuk

Teknis Penganggaran, Pelaksanaan, dan Penatausahaan, serta Pertanggungjawaban Dana BOS Satuan Pendidikan Negeri yang Diselenggarakan oleh Kab/Kota pada APBD.

\section{Peran Serta Sekolah dan Masyarakat}

Berdasarkan kajian Bank Dunia (2014) disimpulkan bahwa pemberdayaan pemangku kepentingan (terutama sekolah dan masyarakat) untuk membuat keputusan sendiri dalam upaya untuk memperbaiki hasil-hasil pendidikan sangatlah penting. Jika melihat konsep partisipasi, maka akan terlihat adanya pergeseran dari sesuatu yang sifatnya turunan dari atas yang mendominasi pelaksanaan kebijakan, menjadi inisiatif yang lebih memperhatikan kepentingan pelaksana, dalam hal ini sekolah dan masyarakat (Storey, 1999).

Al-Samarrai et al. (2014: 1) menyimpulkan bahwa banyak negara telah mengakui bahwa sekolah dan masyarakat lebih tepat posisinya dibandingkan pemerintah dalam pengelolaan pendidikan di sekolah. Kesimpulan inimendorong banyak negara untuk memperkenalkan reformasi manajemen berbasis sekolah yang juga melibatkan masyarakat yang bertujuan untuk memberikan otonomi yang lebih besar kepada sekolah dan masyarakat yang dilayaninya untuk mengelola urusan mereka sendiri. Reformasi ini juga telah mendukung akuntabilitas sekolah yang lebih kuat melalui pembentukan organisasi pengaturan sekolah yang lebih inklusif dan melibatkan orang tua serta masyarakat setempat yang berasal dari kalangan yang lebih luas (AlSamarrai et al., 2014: 1).

Manajemen berbasis sekolah akan terlihat jelas jika ada pemberian dana atau bantuan secara langsung kepada sekolah guna menunjang pelaksanaan pendidikan di sekolah bersangkutan. Sistem ini tidak seperti pendanaan pemerintah yang didapat sekolah secara rutin, karena bantuan langsung mendorong sekolah untuk berinovasi dalam penggunaan bantuan sesuai dengan ketentuan yang telah ditetapkan. Jika dilakukan perbandingan, penggunaan bantuan atau model pengelolaan bantuan setiap negara akan berbeda antara satu dengan yang lain. Misalnya di Australia dan Inggris, sekolah dengan leluasa mengalokasikan dana bantuan untuk pengeluaran rutin sekolah, sedangkan di Malaysia dan Thailand sekolah hanya menggunakan dana bantuan untuk biaya operasional selain gaji (AlSamarrai et al., 2014: 2)

Di Indonesia, pengelolaan dana BOS sejak awal dilakukan oleh sekolah bekerja sama dengan masyarakat yang tergabung dalam komite sekolah. Batasan atau aturan yang menjadi pedoman sekolah dan masyarakat adalah standar pelaksanaan yang tertuang dalam beberapa petunjuk teknis yang dikeluarkan oleh kementerian terkait seperti telah disampaikan di atas.

\section{Permasalahan Bantuan Operasional Sekolah di Banda Aceh, Provinsi Aceh}

Dalam kesempatan turun lapangan ke Kota Banda Aceh di paruh terakhir 2017, hasil wawancara dengan kepala sekolah dan diskusi terfokus dengan guru-guru di sekolah dasar negeri dan sekolah swasta keagamaan(Muhammadiyah), ditemui bahwa dana BOS jelas sangat dibutuhkan oleh sekolah.Walaupun sebenarnya pemerintah setempat dengan dukungan pemerintah pusat sudah menetapkan bahwa penduduk Aceh yang berusia 7 s.d. 15 tidak akan dipungut biaya dan dijamin keberlanjutan pendidikan dasarnya. Karena dengan adanya BOS alokasi dana lainnya tidak lagi diperkenankan seperti halnya pengenaan pungutan-pungutan, atau iuran orang tua siswa. Apalagi saat ini ada Saber Pungli yang 
melarang pungutan-pungutan di luar struktur resmi. Jumlah dana BOS yang diterima sekolah didasarkan pada jumlah peserta didik riil karena pengelolaan dan pertanggungjawabannya disatukan dengan sekolah induk.

Jumlah responden di Banda Aceh adalah sebanyak 17 orang. Usia responden sangat beragam, yakni usia 17 s.d. 30 tahun 5,8\%, 31 s.d. 40 tahun $17,65 \%, 41$ s.d. 50 tahun $41,18 \%, 51$ s.d. 60 tahun $32,29 \%$ dan tidak ada yang berusia lebih dari 60 tahun. Dengan demikian, mayoritas responden berada pada rentang 41 s.d. 50 tahun. Seluruh responden $(100 \%)$ adalah perempuan. Adapun dilihat dari pendidikan terakhir, mayoritas responden berpendidikan diploma/ sarjana $(88,24 \%)$, kemudian berpendidikan SLTA dan pascasarjana (masing-masing 5,88\%). Berdasarkan ragam pekerjaan, jenis pekerjaan responden dengan persentase tertinggi adalah PNS guru $(82,35 \%)$ dan honorer guru/guru swasta $(17,65 \%)$.

Salah satu desakan dari sekolah dasar negeri di Kota Banda Aceh yang sangat mendukung keberadaan dana BOS adalah peruntukan dana BOS bagi guru honorer. Namun demikian, petunjuk teknis (juknis) penggunaan BOS mensyaratkan agar guru honorer yang diberi kompensasi dengan memanfaatkan dana BOS harus mempunyai latar belakang pendidikan yang linear. Aturan Kemdiknas ini baru dikeluarkan pada tahun 2017 sedangkan keberadaan guru honorer ada yang sudah lebih dari lima tahun.

Ketidaksesuaian linearitas pendidikan disebabkan banyaknya dari guru honorer tersebut yang walaupun latar belakang pendidikannya S-1 pendidikan, tetapi pendidikan lanjutannya adalah non-pendidikan. Jika pengaturan linear diberlakukan, maka sekolah ditempatkan pada posisi memberhentikan guru, dan ini sulit dilakukan.

Untuk sekolah yang menerapkan manajemen yang lebih moderat, terkadang keberadaan guru honorer yang tidak terikat kerja dengan pihak lain dan dapat dipanggil sewaktu-waktu sangat membantu, terutama ketika guru tetap berhalangan hadir. Diharapkan tanggung jawab guru honorer ini ada di pihak pemerintah, dan bukan di pihak sekolah.

Khusus untuk sekolah swasta, terutama sekolah swasta yang tidak mempunyai sumber dana yang tetap, keberadaan dana BOS sangat membantu keberlangsungan sekolah. Dana BOS untuk sekolah swasta biasanya digunakan untuk membayar guru honorer (sesuai juknis tidak boleh melebihi 15 persen) dan juga untuk melengkapi laboratorium. Ada harapan agar dana BOS untuk sekolah swasta lebih ditingkatkan terkait dengan jumlah siswa yang tentu saja lebih sedikit dari sekolah negeri. Sekolah negeri juga ingin agar ada peningkatan anggaran untuk BOS dari yang saat ini Rp800.000 untuk satu anak di SD, menjadi Rp1.000.000. Dana BOS akan digunakan untuk membayar guru honorer dan operasional sekolah.

Selain itu, keberadaan dana BOS sangat dirasakan membantu terutama ketika pada saat ujian akhir, mulai diberlakukan ujian berbasis komputer. Untuk sekolah yang belum lengkap peralatan komputernya, maka terpaksa dana BOS digunakan untuk meminjam komputer di sekolah lain.

\section{Permasalahan Bantuan Operasional Sekolah di Kota Pontianak, Provinsi Kalimantan Barat}

Dalam kurun waktu yang tidak berjauhan dari saat turun lapangan ke Kota Banda Aceh, sempat dilakukan wawancara dengan pihak sekolah di beberapa sekolah di Kota Pontianak, Kalimantan Barat. Jumlah responden di Kota Pontianak sebanyak 16 orang. Usia responden sangat beragam, yakni usia 31 s.d. 40 tahun $31,25 \%, 41$ s.d. 50 tahun $56.25 \%$, dan 51 s.d. 60 tahun 12,50\%. Dengan demikian, mayoritas responden berada pada rentang 41 s.d. 50 tahun.

Responden terdiri dari $50 \%$ perempuan dan 50\% laki-laki. Adapun dilihat dari pendidikan terakhir, mayoritas responden berpendidikan diploma/sarjana (68,75\%), kemudian berpendidikan SLTA $(18,75 \%)$ dan berpendidikan pascasarjana (12,50\%). Berdasarkan ragam pekerjaan, jenis pekerjaan responden dengan persentase tertinggi adalah: guru swasta $(43,75 \%)$, guru negeri (PNS) $(31,25 \%)$, dan karyawan swasta $(18,75 \%)$. 
Salah satu pengalaman yang dirasakan sekolah dalam pengelolaan BOS adalah 'kompromi' yang dilakukan oleh orang tua penerima manfaat dan sudah disepakati bersama terkadang tetap muncul dan di-blow-up di media massa. Akibatnya, pengelola BOS di sekolah tidak lagi mau mengelola dana BOS karena khawatir dibenturkan pada berbagai kepentingan yang terkadang bertentangan dengan hati nurani. Sementara waktu dan tenaga yang dikeluarkan pengelola BOS (pihak sekolah) tidaklah sedikit.

Selain itu, ada kekhawatiran dari para guru karena pemanfaatan BOS dianggap kurang tepat jika dilihat dari kondisi di lapangan. Siswa lebih mengutamakan barang konsumtif yang tidak berkaitan langsung dengan pendidikannya, yang mengakibatkan proses belajar mengajar tidak berjalan dengan baik. Bahkan terkadang alat tulis saja tidak dimiliki oleh para siswa yang menerima manfaat BOS.

Di beberapa sekolah yang menggunakan dana BOS untuk kompensasi guru honorer, kejadian di tahun 2016 cukup menjadi trauma tersendiri bagi kepala sekolah. Di tahun tersebut, Provinsi Kalimantan Barat sempat mengalami kesulitan pencairan dana BOS dalam kurun waktu tiga sampai empat bulan. Akibatnya kepala sekolah harus memutar otak untuk mencari dana talangan pengganti sementara pembayaran kompensasi guru honorer.

Selain dana BOS, khusus untuk sekolah swasta, terkadang mereka merasakan perbedaan perlakuan dari dinas pendidikan dalam hal bantuan rehabilitasi kelas. Ada keinginan agar sekolah swasta (walaupun jika dilihat dari kondisi sarana dan prasarana sudah lebih baik daripada sekolah negeri) juga mendapatkan bantuan, terutama karena utang pengelolaan sekolah yang sebenarnya tidak diketahui dinas pendidikan.

Salah satu kasus yang ditemui di Pontianak adalah pembelian buku teks wajib K13 yang diharuskan melalui toko online dengan menggunakan dana BOS. Permasalahan ditemui karena terkadang persediaan di toko online sudah habis, dan tidak jelas kapan akan siap untuk dipesan kembali. Akibatnya proses belajar mengajar di sekolah terganggu. Sebaiknya buku tidak dimonopoli beberapa penerbit saja, dan mudah untuk dicari di pasaran dengan harga yang dipatok pemerintah.

\section{Permasalahan Bantuan Operasional Sekolah di Kota Manado, Sulawesi Utara}

Selain Banda Aceh dan Pontianak, turun lapangan dalam rangka pengambilan data juga dilaksanakan di Kota Manado. Jumlah responden di Kota Manado adalah sebanyak 8 orang. Usia responden tidak terlalu beragam, yakni usia 41 s.d. 50 tahun $25,00 \%$, dan 51 s.d. 60 tahun $75,00 \%$. Dengan demikian, mayoritas responden berada pada rentang 51 s.d. 60 tahun. Responden terdiri dari $75,00 \%$ perempuan dan $25,00 \%$ lakilaki. Adapun dilihat dari pendidikan terakhir, mayoritas responden berpendidikan diploma/ sarjana $(87,50 \%)$, kemudian berpendidikan pascasarjana (12,50\%). Berdasarkan ragam pekerjaan, seluruh responden (100\%) adalah PNS (guru) walaupun beberapa di antaranya ditugaskan di sekolah swasta.

Dari hasil wawancara dengan tenaga kependidikan di dua SD swasta dan SMP negeri di Kota Manado terungkap bahwa permasalahan yang dihadapi adalah kerapnya dana BOS terlambat pencairannya, dan dalam kasus demikian, sekolah biasanya menutupi dengan dana pribadi kepala sekolah atau berutang (kepada rekanan) agar kegiatan operasional sekolah tetap bisa berjalan, seperti untuk pengadaan alat tulis. Pengadaan alat tulis dalam rangka pengajaran merupakan sesuatu yang tidak dapat ditunda bagi sekolah.

Permasalahan lain terungkap bahwa alokasi dana BOS dari suatu kurun waktu bisa turun drastis jumlahnya. Seperti yang terjadi pada sebuah SMP negeri, tenaga pendidiknya mengakui bahwa di tahun 2016 dana BOS yang diperoleh sebesar Rp240 juta, tetapi di tahun 2017 menjadi Rp180 juta di Triwulan 2, kemudian Triwulan 3 menjadi Rp190 juta. Akibatnya, sekolah harus melakukan pemangkasan beberapa pos pengeluaran anggaran. Padahal jika hitungannya berbasis jumlah siswa, sekolah tersebut tidak mengalami perubahan yang berarti; kalaupun datanya mengalami penurunan, maka jumlahnya tidak signifikan. 
Penurunan dana BOS seperti yang dialami SMP negeri di Kota Manado sudah tentu mengganggu kelancaran pemenuhan kebutuhan operasional sekolah yang tidak bisa ditunda, seperti pengadaan alat tulis, pembayaran gaji guru (honorer) dan petugas sekolah lainnya agar sekolah tidak terhambat kegiatannya. Apalagi, kebutuhan semacam ini adalah tergolong pembiayaan rutin yang wajib diadakan setiap tahun atau triwulan.

Penurunan dana BOS, berdasarkan hasil wawancara dengan salah satu SD swasta, berdampak pada pengadaan kebutuhan sekolah yang sudah direncanakan di tahun sebelumnya. Dana BOS yang ada habis untuk kebutuhan satu atau tiga bulan ke depan. Menghadapi kondisi demikian, biasanya sekolah melakukan rapat internal terlebih dahulu, yang dari hasil pembicaraannya didokumentasikan untuk dikonsultasikan lebih lanjut dengan pihak dinas pendidikan.

Permasalahan lain yang juga perlu diantisipasi adalah penggunaan dana BOS yang berkaitan dengan kegiatan ekstra kurikuler (ekskul), misalnya kegiatan/kunjungan ekskul ke luar kota. Dari hasil wawancara terhadap salah satu SD swasta, terjadi kasus mengenai ketidaksepahaman orang tua siswa dan pihak sekolah terhadap pelaksanaan kegiatan sekolah yang dilaksanakan di Bali. Sebagian orang tua siswa berpandangan bahwa dana BOS dapat digunakan untuk kegiatan ekskul tersebut, tetapi pihak sekolah berpandangan bahwa dana BOS tidak bisa digunakan untuk kegiatan ekskul semacam itu, meskipun kegiatan ekskul tersebut sangat bermanfaat bagi kemajuan sekolah.

Tidak kalah penting, dana bagi perbaikan sarana prasarana sekolah juga harus dipikirkan. Persoalannya, untuk memperoleh dana bagi perbaikan bangunan sekolah adalah tidak mudah dan memerlukan waktu lama. Dari penjelasan sebuah SMP negeri di Kota Manado terungkap bahwa bangunan sekolahnya sudah berdiri sejak 1977, tetapi baru pada tahun 2017 bisa melakukan rehabilitasi besar-besaran yang mencakup kelaskelas dan ruang guru, serta ruangan pendukung lainnya.

\section{Evaluasi Program Bantuan Operasional Sekolah}

Seperti disampaikan oleh Bank Dunia (2014), sulit untuk mengurai peran BOS dalam mengurangi biaya pendidikan yang ditanggung oleh rumah tangga. Tetapi jika dihitung dari Angka Partisipasi Kasar (APK), memang terjadi pengurangan kesenjangan partisipasi pendidikan antarkelompok masyarakat (Kemendikbud, 2018). Disampaikan bahwa $56,68 \%$ penerima BOS adalah sekolah negeri dengan jumlah siswa kurang dari 168 peserta didik. Selain itu, $0,05 \%$ sekolah swasta dengan jumlah melebihi 672 peserta didik menolak dana BOS. Bahkan posisi DKI Jakarta berada lebih dekat dengan tidak menerima BOS. Artinya banyak sekolah di Provinsi DKI yang tidak menerima BOS dibandingkan sekolah-sekolah di provinsi lain (Kemendikbud, 2018).

Program BOS mungkin pada awalnya memberikan kontribusi terhadap peningkatan angka partisipasi pada tingkat SMP di kalangan rumah tangga miskin. Analisis Bank Dunia memperlihatkan adanya peningkatan besar dalam angka partisipasi di tingkat SMP, yaitu sekitar lima poin persentase, untuk rumah tangga termiskin yang langsung terjadi setelah BOS diperkenalkan, walau tampaknya bersifat sementara, dan angka partisipasi kembali ke tren jangka panjang yang tidak berfluktuasi meski selanjutnya ada peningkatan dana hibah BOS per siswa (Al-Samarrai et al., 2014: 9).

Sebagai salah satu upaya reformasi di bidang pendidikan untuk lebih meningkatkan peran sekolah dan masyarakat, maka partisipasi masih menjadi upaya besar yang harus dilakukan bersama. Meskipun partisipasi komite sekolah kurang, peran terkuat mereka berpusat di sekitar masalah penggunaan dana BOS dan pengawasan masalah keuangan secara lebih umum. Pada tahun 2010 Bank Dunia menemukan bahwa lebih dari 60\% dari kepala sekolah melaporkan bahwa komite sekolah terlibat dalam pengambilan keputusan akhir yang menyangkut masalahmasalah tersebut. Mungkin bukan hal yang mengejutkan apabila komite sekolah jarang terlibat dalam pengambilan keputusan tentang 
pedagogi dan isu-isu pengajaran (Al-Samarrai et al., 2014: 10). Temuan ini mengingatkan pentingnya keterbukaan dalam pengambilan keputusan di kalangan komunitas sekolah.

Hal ini ditemui ketika turun lapangan ke tiga kota di atas, karena peran komite sekolah dan diskusi bersama antara sekolah dengan orang tua siswa menjadi inti dari pemanfaatan BOS yang lebih baik. Meskipun BOS telah memberikan peran bagi komite sekolah, ada kelemahan penting terkait dengan sejauh mana mereka telah menjalankan peran masing-masing pihak dalam komite sekolah secara efektif.

Diskusi di lapangan dengan anggota komite yang bukan kepala sekolah dan bukan guru mengakui terkadang anggota komite jarang diajak berunding sejak awal dalam pengambilan keputusan tentang alokasi dana BOS. Hal yang lebih sering terjadi adalah kepala sekolah dan guru menyepakati alokasi dana BOS dan kemudian menyampaikan keputusan mereka kepada ketua komite sekolah untuk mendapatkan persetujuan.

Ketika ada keinginan dari ketua komite sekolah untuk menginformasikan hal tersebut kepada orang tua siswa, baru orang tua siswa akan merespons dan biasanya respons tidak selalu positif. Di sini peran dinas pendidikan menjadi penting untuk menjadi penengah agar keputusan yang diambil komite sekolah dapat diterima semua pihak. Keinginan anggota komite sekolah adalah agar ada transparansi dan akuntabilitas pengelolaan dana BOS sejak awal.

\section{Penutup}

Saat ini, Program BOS memiliki pengaruh besar terhadap biaya yang menjadi beban rumah tangga. Hal ini dijadikan kesimpulan karena telah ada juga diskusi intensif dengan keluarga yang mempunyai anak yang mendapatkan dana BOS dari sekolah terutama keluarga penerima manfaat Program Keluarga Sejahtera. Selain itu telah ada upaya melibatkan masyarakat secara langsung, walaupun sifatnya masih perwakilan dalam komite sekolah, dalam mengelola bantuan yang berasal dari Program BOS

Hasil positif ini menunjukan tetap perlunya dilakukan pengkajian agar BOS tetap mendapatkan dukungan positif dari pemerintah provinsi/kabupaten/kota, dan juga dari sekolah serta masyarakat. Partisipasi masyarakat, terutama jika menyangkut pendanaan, tidak berarti tanpa pengawasan. Harus ada kepastian transparansi dan akuntabilitas dari pemanfaatan dana yang tetap dilaporkan ke masyarakat dan tidak bersifat memaksa.

Secara khusus, saran yang dapat disampaikan adalah:

1. Menyesuaikan BOS agar terus memberikan perhatian khusus pada peningkatan mutu pendidikan, karena hingga saat ini peran masyarakat melalui komite sekolah masih sebatas pada pengelolaan dana Program BOS dan belum pada aspek pembelajaran di sekolah.

2. Lebih berupaya memanfaatkan dana Program BOS untuk membantu meningkatkan mutu pendidikan dan bukan untuk menangani kekurangan tenaga pengajar sementara (honorer) di sekolah.

3. Memperbaiki koordinasi antara dana BOS dengan dana lainnya untuk sekolah terutama yang berasal dari orang tua siswa.

4. Menggiatkan kembali peran Program BOS dalam memberdayakan sekolah dan masyarakat setempat dalam manajemen komite sekolah yang lebih baik. 


\section{DAFTAR PUSTAKA}

Al-Samarrai, S., Fasih, T., Hasan, A. \& Syukriyah, D. (2014). Pengkajian Peran Program Bantuan Operasional Sekolah (BOS) dalam Memperbaiki Hasil-Hasil Pendidikan di Indonesia. Jakarta: Bank Dunia.

Bank Dunia. (2015). Memperbaiki Pendidikan melalui Program Bantuan Operasional Sekolah (BOS) di Indonesia. Naskah Kebijakan. Jakarta: Bank Dunia.

Bank Indonesia. (2005). Laporan Perekonomian Indonesia 2005. Jakarta: Bank Indonesia.

Kharisma, B. (2013). Dampak Program Bantuan Operasional Sekolah (BOS) terhadap Tingkat Putus Sekolah di Indonesia: Analisis DID. Jurnal Ekonomi Kuantitatif Terapan 6(1) Februari 2013, hlm. 7-15.

Miles, M.B., Huberman, A.M. (1994). Qualitative Data Analysis: An Expanded Sourcebook. California: Sage Publication, Inc.

Peraturan Menteri Pendidikan dan Kebudayaan Republik Indonesia Nomor 76 Tahun 2012 tentang Juknis Penggunaan dan Pertanggungjawaban Keuangan Dana BOS Tahun 2013 (2012).

Peraturan Menteri Pendidikan dan Kebudayaan Nomor 18 Tahun 2019 tentang Perubahan Juknis BOS 2019 (2019).

Peraturan Menteri Pendidikan dan Kebudayaan Nomor 18 Tahun 2018 tentang Bantuan Operasional Sekolah (2018).

Priowirjanto, G. H., Prakoso, B. S., Nuryanto, A., dan Mustafa, K. (2018). Penerapan SistemPengelolaan Data Pokok Pendidikan (DAPODIK). Makalah disampaikan dalam e-Indonesia Initiative 2008 - Konferensi dan Temu Nasional Teknologi Informasi dan Komunikasi untuk Indonesia, Jakarta, 21-23 Mei 2008.

Program Bantuan Siswa Miskin, diakses di http:// www.tnp2k.go.id/id/tanya-jawab/klaster-i/ program-bantuan-siswa-miskin-bsm/, pada 28 Maret 2018.

Program Indonesia Pintar Melalui Kartu Indonesia Pintar (KIP), diakses di http://www.tnp2k.go.id/ id/tanya-jawab/klaster-i/program-indonesiapintar-melalui-kartu-indonesia-pintar-kip/, pada 28 Maret 2018.

SMERU. (2006). Kajian Cepat PKPSBBM Bidang Pendidikan: Bantuan Operasional Sekolah (BOS) 2005. Jakarta: Smeru.
Storey. D. (1999). Issues of Integration, Participation and Empowerment in Rural Development: The Case of LEADER in the Republic of Ireland. Journal of Rural Studies, 15, 307-315. 